\title{
What do we know about Anisotremus moricandi (Teleostei: Haemulidae), an endangered reef fish?
}

\author{
Thelma Lúcia Pereira Dias \\ Biota Neotropica $v 7(n 2)$ \\ http://www.biotaneotropica.org.br/v7n2/pt/abstract?short-communication+bn04207022007
}

Recebido em 26/02/07

Versão reformulada recebida em 15/06/07

Publicado em 19/07/07

Programa de Pós-Graduação em Ciências Biológicas (Zoologia), Departamento de Sistemática e Ecologia, Universidade Federal da Paraíba, Campus I, CEP 58051-900, João Pessoa, PB, Brasil

Corresponding author: Thelma Lúcia Pereira Dias, e-mail: mangrove_rn@yahoo.com.br

\begin{abstract}
Dias, T.L.P. What do we know about Anisotremus moricandi (Teleostei: Haemulidae), an endangered reef fish? Biota Neotrop. May/Aug 2007 vol. 7, no. 2. http://www.biotaneotropica.org.br/v7n2/pt/abstract?shortcommunication+bn04207022007. ISSN 1676-0603.

This article provides general information on habitat, behavior, and conservation status of Anisotremus moricandi and reinforces its distribution to the western Atlantic. The species inhabits rocky reefs with low coralline overgrowth and it is found in reef crevices in small groups or solitary individuals. The distribution of A. moricandi seems to be discontinuous occurring in the coasts of Panama (Caribbean side), Aruba, Colombia, Orchila Island (Venezuela) and in Brazil (from Ceará State to Espírito Santo State).

Keywords: coastal reefs, distribution, habitat, conservation, behavior, northeastern Brazil.

Resumo

Dias, T.L.P. O que nós sabemos sobre Anisotremus moricandi (Teleostei: Haemulidae), um peixe recifal em perigo de extinção? Biota Neotrop. May/Aug 2007 vol. 7, no. 2. http://www.biotaneotropica.org.br/v7n2/ pt/abstract?short-communication+bn04207022007. ISSN 1676-0603.

Este artigo fornece informações gerais acerca do habitat, comportamento e estado de conservação de Anisotremus moricandi e reforça sua distribução no Atlântico Ocidental. A espécie habita recifes rochosos com baixo crecimento coralino e é encontrada em fendas do recife em pequenos grupos ou solitária. A distribuição de A. moricandi parece ser descontínua, ocorrendo nas costas do Panamá (lado Caribenho), Aruba, Colômbia, Ilha Orquila (Venezuela) e no Brasil (do Ceará ao Espírito Santo).
\end{abstract}

Palavras-chave: recifes costeiros, distribuição, hábitat, conservação, comportamento, nordeste do Brasil. 


\section{Introduction}

The brownstriped grunt, Anisotremus moricandi Ranzani, 1842, is a bony fish belonging to the family Haemulidae. Ranzani (1842) originally described this species from Bahia State, Northeastern Brazil, and after several misidentifications, it was rediscovered and redescribed by Acero \& Garzón (1982). Since its first description and its more recent rediscovery, only a few scientific publications (e.g. Jordan \& Evermann 1898, Meek \& Hildebrand 1925, Humann \& Deloach 2002) cited the existence of this species. Although $A$. moricandi is a relatively common species in the northeastern Brazilian coastal reefs (T. Dias, unpublished data) and in the Espírito Santo State $\left(20^{\circ} \mathrm{S}\right)$ (its southern limit according to Moura et al. 1999), this species remains poorly studied.

Although A. moricandi is an endangered species, accordingly to the IUCN (2006), data on the natural history and abundance of this species is urgently needed. The present study provides basic data on the conservation status, threats, habitat, behavior and distribution of this threatened fish species, and suggests measures for the conservation of A. moricandi and their habitat.

\section{Material and Methods}

This study is based on data obtained from field observations in Brazil and from literature (e.g. Jordan \& Evermann 1898, Meek \& Hildebrand 1925, Acero \& Garzón 1982, Humann \& Deloach 2002). Underwater random observations were carried out from January to May 2002 and January 2007 at three coastal reefs (known as beachrocks) of Paraíba state: Poço reef $\left(07^{\circ} 01^{\prime} \mathrm{S}\right.$ and $\left.34^{\circ} 48^{\prime} \mathrm{W}\right)$, Picãozinho reef $\left(07^{\circ} 07^{\prime} \mathrm{S}\right.$ and $\left.34^{\circ} 48^{\prime} \mathrm{W}\right)$ and Areia Vermelha reef $\left(07^{\circ} 01^{\prime} \mathrm{S}\right.$ and $\left.34^{\circ} 49^{\prime} \mathrm{W}\right)$. Habitat characteristics and species behavior were recorded during 10 hours of underwater observations during the day (five hours) and at night (five hours). Data were recorded on an underwater slate. Depth in the study sites ranged from 0.5 to $6.0 \mathrm{~m}$ and water temperature remained between $27-29^{\circ} \mathrm{C}$ (day) and $26-28^{\circ} \mathrm{C}$ (at night).

\section{Results and Discussion}

In the coastal reefs of Paraíba state, A. moricandi inhabits shallow waters ( 0.5 to $4.5 \mathrm{~m}$ deep) usually near reef crevices. It may be sighted solitary (Figure 1) or in small groups (2 to 12 individuals) (Figure 2). Feitoza (2001) also observed individuals of this species in shallow reefs (1 to $7 \mathrm{~km}$ off the shoreline) off Rio Grande do

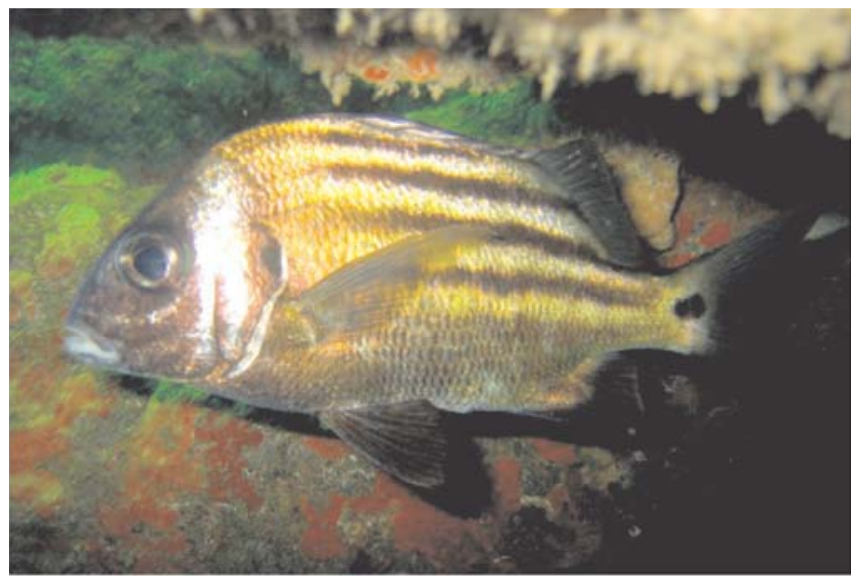

Figure 1. Solitary adult Anisotremus moricandi in a reef crevice at Bahia coast, Northeastern Brazil. Photo by A. Bertoncini.

Figura 1. Adulto solitário de Anisotremus moricandi em uma fenda recifal na costa da Bahia, Nordeste do Brasil. Foto por A. Bertoncini.
Norte state. According to Acero \& Garzón (1982), A. moricandi seems to avoid insular conditions and is found in turbid, continental areas, apparently restricted to rocky reefs with little, if any, coralline overgrowth. In Paraíba, the coastal reefs where the species occur have clear water ( $>8 \mathrm{~m}$ horizontal visibility) during low tides in the summer, but during the rain season or during high tides, these reefs presents turbid waters $(<3 \mathrm{~m}$ horizontal visibility).

Some specimens deposited in Brazilian Museums were collected from areas relatively distant from mainland, such as the Abrolhos Archipelago, about $50 \mathrm{~km}$ offshore southern Bahia State. This area is located in an extensive shallow continental shelf that presents relatively turbid waters due to continental drainage and the high sedimentation rates caused by human activities (Coutinho et al. 1993, Leão \& Kikuchi 2001). These characteristics support the hypothesis that $A$. moricandi possibly prefers turbid waters, but not necessarily avoids coastal insular conditions. However, between the Abrolhos Archipelago and the Bahia coast there is a very large development of stone steps and coral growth (mainly the Brazilian endemic species Mussismilia braziliensis) (Leão \& Kikuchi 2001), which probably helped the colonisation of more distant areas. The factors that favour the settlement and future establishment of A. moricandi populations, such as reef topography, food availability, water and habitat characteristics demand further studies.

In terms of activity period, this species seems to be more active at night since specimens collected during the day had empty stomachs (Acero \& Garzón 1982, T. Dias, unpublished data). Acero \& Garzón (1982) examined the stomach of one individual of A. moricandi collected at midday and no food was found, but the intestinal tract contained digested remains of crabs, filamentous algae, gastropod shells, and polychaete worms, suggesting an omnivorous diet. In some coastal reefs of Paraíba state (about $0.8 \mathrm{~km}$ distant from the shoreline), Brazil, the species was seen foraging on algae patches at daylight hours.

Since 1996 A. moricandi is included in the IUCN Red List of Threatened Animals (IUCN 1996). Although this list has no legislative value, it acts as warning flag to alert people to species that may be in danger. In the case of $A$. moricandi, the species is listed in the category "endangered" (criteria A2c). This category means that the best available evidence indicates that it could be facing a very high risk of extinction in the wild. The criteria A2c indicates that the species presents a reduction in population size due to several factors,

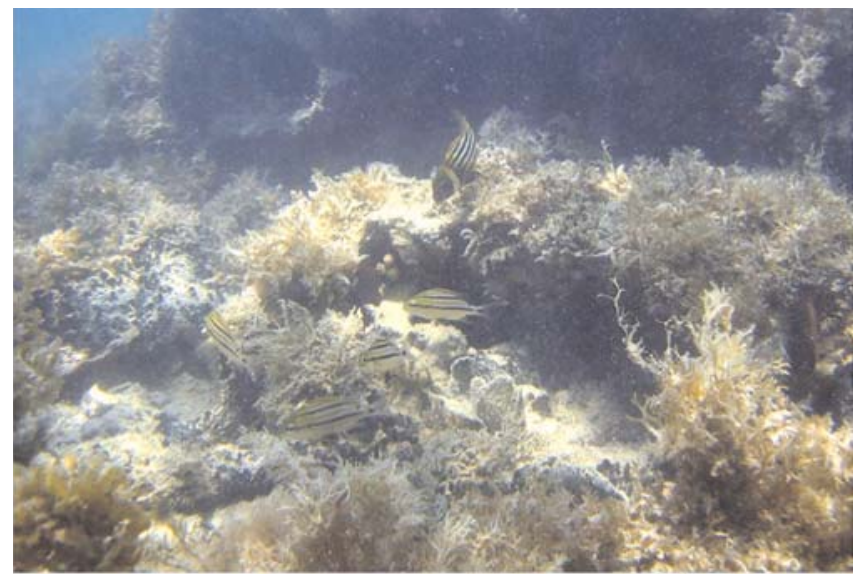

Figure 2. Small group of Anisotremus moricandi at a coastal reef, Paraíba coast, Northeastern Brazil. Photo by T. Dias.

Figura 2. Pequeno grupo de Anisotremus moricandi em um recife costeiro, costa da Paraíba, Nordeste do Brasil. Foto por T. Dias. 
including a decline in area of occupancy, extent of occurrence and/ or quality of habitat (Hilton-Taylor 2000).

In fact, the distribution of $A$. moricandi is apparently discontinuous and according to Acero \& Garzón (1982), it occurs in the coasts of Panama (Caribbean side), Colombia, and in Brazil. According to Lindeman \& Toxey (2003), the species also occurs in the Orchila Island (Venezuela) and in Aruba. In the Colombian Caribbean it has been registered in Tierra Bomba and Isla Arena (Departamento de Bolívar) and in the bays of Santa Marta and Gayraca (Departamento del Magdalena) (A. Acero, personal communication). In the Brazilian coast, it occurs from Ceará State $\left(3^{\circ} \mathrm{S}\right)$ to Espírito Santo State $\left(20^{\circ} \mathrm{S}\right)$ (cf. Moura et al. 1999).

In terms of human utilisation, $A$. moricandi is not a commercially important fish, but it is now being introduced into the marine aquarium trade (Gasparini et al. 2005). In some coastal areas it is used as food by small-scale fishers and it is caught by spearfishing, tarrafa net fishing and hook and line. According to Floeter et al. (2006), the species is suffering a heavy fishing pressure in Southeast Brazil. At present, the conservation status of A. moricandi in Brazil is still poorly known. However, the additional pressure of the aquarium trade and the increased utilisation of this species in other markets can bring serious negative impacts to this threatened fish species.

Although A. moricandi is not threatened due to high commercial exploitation, as occurs to the majority of marine organisms that are endangered, it has been a victim of the human impact on coastal areas. These impacts include disorganised recreational activities on reefs, high sedimentation rates coming from the mainland, and discharges of pollutants that reach coastal reefs (Hodgson 1999). Another threat is the direct destruction of reef environments through the anchorage of boats and retreat of reef builders. For example, in places such as Areia Vermelha Reef and Picãozinho Reef (Paraíba, Brazil), reef walking on exposed surfaces of reefs, boat anchors, diving, fishing and extraction of corals for aquarium purposes could damage seriously the reef ecosystem. Since there is a dearth of information on the biology and ecology of A. moricandi coupled to the fact that this species is at risk of extinction, habitat protection is an important first step to protect this species, and the study of population parameters (e.g. growth rates, mortality estimates, reproduction) and ecology in the wild is a critical information to implement conservation measures.

Considering that $A$. moricandi is apparently range-restricted and unstudied, the major threat for this species is the habitat degradation. Some conservation recommendations are: (a) the protection of reef environments through the implantation of Marine Protected Areas, (b) the regulation of the exploitation of A. moricandi for fisheries and aquarium purposes, and (c) the regulation of human activities such as tourism and recreational fishery in coastal reef areas.

\section{Acknowledgments}

I am very grateful to L.C.P. Damasceno and B.M. Feitoza for help in the fieldwork. A. Bertoncini, J. L. Gasparini and S. R. Floeter kindly provided constructive comments on the manuscript. Special thanks to C. B. Vuelta for providing many references. Financial support was provided by CAPES (Brazilian Ministry of Education).

\section{References}

ACERO P, A. \& GARZÓN, F.J. 1982. Rediscovery of Anisotremus moricandi (Perciformes: Haemulidae), including a redescription of the species and comments on its ecology and distribution. Copeia 1982:613-618.

COUTINHO, R., VILLAÇA, R.C., MAGALHÃES, C.A., GUIMARAENS, M.A., APOLINÁRIO, M. \& MURICY, G. 1993. Influência antrópica nos ecossistemas coralinos da região de Abrolhos, Bahia, Brasil. Acta Biol. Leopold. 15:133-144

FEITOZA, B. M. 2001. Composition and community structure of reef fishes of Risca do Zumbi, Rio Grande do Norte. M. Sc. Thesis, Department of Systematics and Ecology, Federal University of Paraíba, Brazil (in portuguese).

FLOETER, S.R., HALPERN, B.S. \& FERREIRA, C.E.L. 2006. Effects of fishing and protection on Brazilian reef fishes. Biol. Conserv. 128:391-402.

GASPARINI, J.L., FLOETER, S.R., FERREIRA, C.E.L. \& SAZIMA, I. 2005. Marine ornamental trade in Brazil. Biodivers. Conserv. 14:2883-2899.

HILTON-TAYLOR, C. (Compiler), 2000. 2000 IUCN Red List of Threatened Species. IUCN, Gland, Switzerland and Cambridge.

HODGSON, G. 1999. A global assessment of human effects on coral reefs. Mar. Pollut. Bull. 38:345-355.

HUMANN, P. \& DELOACH, N. 2002. Reef Fish Identification - Florida, Caribbean, Bahamas. New World Publications, Inc. Jacksonville.

IUCN, 1996. 1996 IUCN Red list of threatened animals. IUCN, Gland, Switzerland.

IUCN, 2006. 2006 IUCN Red List of Threatened Species. Avaiable in: www.redlist.org. (Downloaded in 06 February 2006).

JORDAN, D.S. \& EVERMANN, B.W. 1898. The fishes of North Middle America. Bull. US Natl. Mus. 47:1241-2183.

LEÃO, Z.M.A. \& KIKUCHI, R.K.P. 2001. The Abrolhos Reefs of Brazil. Ecol. Stud. 144:83-96.

LINDEMAN, K.C. \& TOXEY, C.S. 2003. Haemulidae. In: Carpenter, K. E. (ed). The living marine resources of the Western Central Atlantic. Volume 3: Bony fishes part 2 (Opistognathida to Molidae). FAO species identification guide for fishery purposes and American Society of Ichthyologist and Herpetologists Special Publication No. 5. FAO, Rome.

MEEK, S.E. \& HILDEBRAND, S.F. 1925. The marine fishes of Panama. Field Mus. Nat. Hist. Zool. Series 15 (Part II):331-707.

MOURA, R.L., GASPARINI, J.L. \& SAZIMA, I. 1999. New records and range extensions of reef fishes in the western south Atlantic, with comments on reef fish distribution along the Brazilian coast. Rev. Bras. Zool. 16:513-530.

RANZANI, C. 1842. De novis speciebus piscium. Dissertatio IV. Nov. Comm. Bonon. 5:340-365. 